\title{
Partnership Model to Improving Civil Farmers Competitiveness in Bondowoso District
}

\author{
Abul Haris Suryo Negoro ${ }^{1 *}$, Abdul Kholiq Azhari², Anastasia Murdyastuti ${ }^{3}$ \\ 1,2,3 Faculty of Social and Political Sciences, University of Jember, East Java, Indonesia
}

\section{A R T I C L E I N F O \\ Article history: \\ Received 19 August 2019 \\ Received in revised form \\ 16 September 2019 \\ Accepted 15 October 2019 \\ Available online 29 \\ November 2019}

Keywords:

Partnership,

Competitiveness, Cassava

Farmers

\begin{abstract}
A B S T R A C T
Business partnerships between medium-sized entrepreneurs, large and small entrepreneurs, are carried out in the partnership triangle to increase added value and product competitiveness. Partnerships can overcome the problems of capital, management, entrepreneurship, technology, and network marketing. Widespread market share and cassava marketing network, as a manifestation of increasing competitiveness and added value of cassava, as well as the realization of the partnership principle. Although the partnership model is pseudo, the implementation of the partnership principle is active, the business competitiveness of cassava farmers tends to be high. The high competitiveness of products is reflected in the large and varied market share of cassava, such as tape businessmen, tapioca flour factories, and sellers/traders of cassava and tape and cakes. Therefore the essential partnership is a transformation for the realization of cassava farmers as competitive producers and entrepreneurs who always produce the products/commodities needed by their customers.
\end{abstract}

\footnotetext{
* Corresponding author.

E-mail addresses: haris.fisip@unej.ac.id (Abul Haris Suryo Negoro)
} 


\section{Introduction}

The limited ownership of production resources of cassava farmers shows capital ownership, technology mastery, market information access, and limited business management skills. The scale of business besides being related to the size of business capital, also with other production factors, namely agricultural land which is defined as land prepared to be cultivated for farming such as rice fields, plants and yards (Soekartawi, 1990). Limited land, business capital, and technology cause a limited quantity of products produced. The low access of small businesses to technology and network marketing will create a discrepancy between the products produced with the quality of goods needed by customers. Low productivity, product quality, and added value as a manifestation of low product competitiveness, and the powerlessness of cassava farmers. The implication for small and weak businesses with limited ownership of production factors and low productivity will result in a low level of welfare

The weak competitiveness of small business products is related to internal problems, namely: (a) the little professionalism of small business managers; (b) limited capital and lack of access to banks and markets, and (c) technological mastery capabilities that are still inadequate (Hafsah, 2000). The limited situation, encouraging cassava farmers will depend on brokers, tape entrepreneurs, and the government, especially the local government. This causes the price of cassava products to be in the control of the broker and the tape entrepreneur as a buyer. The position of cassava farmers as producers in buying and selling transactions is in a weak position. The weak bargaining position of these farmers will cause difficulties for farmers to get out of the cycle of poverty, entrapment of moneylenders, and challenges in increasing their production competitiveness.

Various kinds of difficulties faced by small businesses such as cassava farmers' business as a people's economy require seriousness and actions that are all out (quite radical from the government) intended to protect the people through state policies that are pro to their interests (Wahab, 1999). Besides that, support from the business community and civil society is also needed. Cassava farmers often find it difficult to gain access to change, given their conditions are small, dry, small capital farmers, limited knowledge, making it difficult to catch up with market demand. Therefore, the policies needed are those that provide fair and fair access to cassava farmers in obtaining inputs, production processes, distribution without any obstacles in entering the market.

In the era of regional autonomy, it provides an opportunity for local governments to create a government structure that is by the needs of the region itself. Good governance requires effective government administration and creating policies that are right on target (Azhari, 2019). Local government policies like this are needed because: First, $52.07 \%$ of the population of Bondowoso Regency, who work and work in the agricultural sector, and $90 \%$ of the land is used for agriculture with $27.66 \%$ using dry land / dry land (BPS Bondowoso Regency, 2016). Second, cassava is a type of cassava plant that is used as food ingredients to meet people's needs, and ribbon/cake ingredients and for tapioca flour. Means cassava is of economic, social, and cultural value. Third, cassava farmers' businesses, besides absorbing labor, also opened a search field in small industries and medium competing raw materials from cassava. Regarding cassava industry business, there are 498 tape business units, with 1,736 workers, there are 450 cassava flour business units, with 1,026 workers, and there are 82 cassava cracker businesses with a workforce of 312 people (District Cooperative, Industry and Trade Office Bondowoso, 2016).

According to Piter (2002), economic agents (economic agents) are not only companies, but also households, governments, and others. This opinion, provides guidance, that economic actors are related to increasing product competitiveness, in addition to the business world, and the government, as well as civil society. Chaitanya with superiority, Hafsah (2000), said that the concept of the latest competitive advantage is how to show the ability to supply (sell) goods/services that are by consumer preferences is a necessary condition for competitiveness. Furthermore, Hafsah (2000) states that the keywords that become indicators of excellence are productivity defined in the economic model as the output divided by inputs. Related to competitiveness indicators, Hafsah (2000) says that the sign of acceptance of a product by the market is the quality suitability desired by consumers (market-driven quality or consumer-driven quality), and consumer loyalty can be achieved if there is a quality guarantee of a product.

Competitive products can be produced by organizations that can guarantee quality and efficiency. Quality products will survive if the organization can maintain good condition, as Muluk said (2018) that the basis of competitive advantage will be achieved through phasing as follows: efficiency, productivity, adaptation, and innovation. Increased competitiveness of products or commodities, encouraging the growth of competitive SMEs, and the opening of knowledge-based employment. The Muluk Opinion shows that the main elements that influence creating added value are productivity and innovation as applications of knowledge in work or business. 
One effort to realize small businesses is to be able to make efficiency and reduce production costs, of course through education and training activities related to production and financial management, as well as entrepreneurship. With entrepreneurship, small entrepreneurs will be able to manage their business creatively and produce innovative products that are carried out efficiently. Besides through Diklat, the application is through partnership. With the principle of mutual need, mutual reinforcement, and mutual benefit, the partnership undertaken will encourage small businesses to be able to make efficiency and reduce production costs. The ability to build efficiency and reduce production costs will increase the profit from the sale of the products produced. Through partnerships between large businesses and small businesses, it can increase productivity, increase market share, increase profits, share the risk, guarantee the supply of raw materials, ensure distribution of marketing. The people's economy which is not supported by substantial capital and advanced technology, which in itself is weak, can survive, even though it must compete with the modern economy that is "efficient" and globalized (Mubyarto, 1997). The statement can show that small businesses must be placed as superior business actors by providing fair and fair access in obtaining input, the process of production, distribution, and national consumption without any obstacle to enter the market (Bobo, 2003). Through partnerships, small businesses as a people's economy have the power to increase productivity, manage their business efficiency, and produce products that are accepted by the market. The indicator of the acceptance of a product by the market is the quality suitability desired by consumers (market-driven quality or consumer-driven quality), and consumer loyalty can be achieved if there is a quality guarantee of a product (Hafsah, 2000). Therefore quality, quantity, and continuity are the glue of business partnerships. Regarding quality, the final product of an organization is determined by whether or not the market is accepted. If successful, it can perpetuate the continuity of the partnership into the main stage of collaboration. At this stage, small businesses as a form of people's economy, really have become empowered both in terms of management and the competitiveness of the products they produce.

Products that have added value require productivity and efficiency as well as value-added products. Partnership business collaboration is synergistic between parties who have strong capital, advanced technology, modern management with those who have raw materials, labor, and land. Through business partnerships, mutual symbiosis is fast, so that the shortcomings and limitations of the business of cassava farmers can be overcome and become an advanced business. And competitive. The business partnership that wants to be realized with its main mission is to help solve the problem of inequality or inequality in terms of business opportunities, income shortages, inequality between regions, and inequality between cities and villages. The problem in this study is how is the model of partnership between actors in increasing the business competitiveness of cassava farmers in Bondowoso District?

\section{Methods}

The type of research used in this study is qualitative research that describes human speech, writing or behavior as the object of research observed, whether in the form of individuals, groups, communities or organizations as a comprehensive or comprehensive form. Miles and Huberman (1992) state that qualitative research is a type of research that is not based on logic alone, but also considers methodological aspects. The focus of research on agricultural business partnerships is to increase the competitiveness of cassava.

This research will be conducted in Bondowoso Regency between March to December 2018 because the area is called the tape production center, which requires cassava base material so that many cassava farmers try to meet those needs. In this study focused on the partnership pattern to obtain agricultural management facilities and a high bargaining position for cassava farming. According to Miles and Huberman (1992) states that the main instruments in qualitative research are the researchers themselves. In this study interactive data analysis was used as stated by Miles and Huberman (1992) which consisted of data reduction, data presentation and conclusion drawing. The flow of data analysis is as follows: 


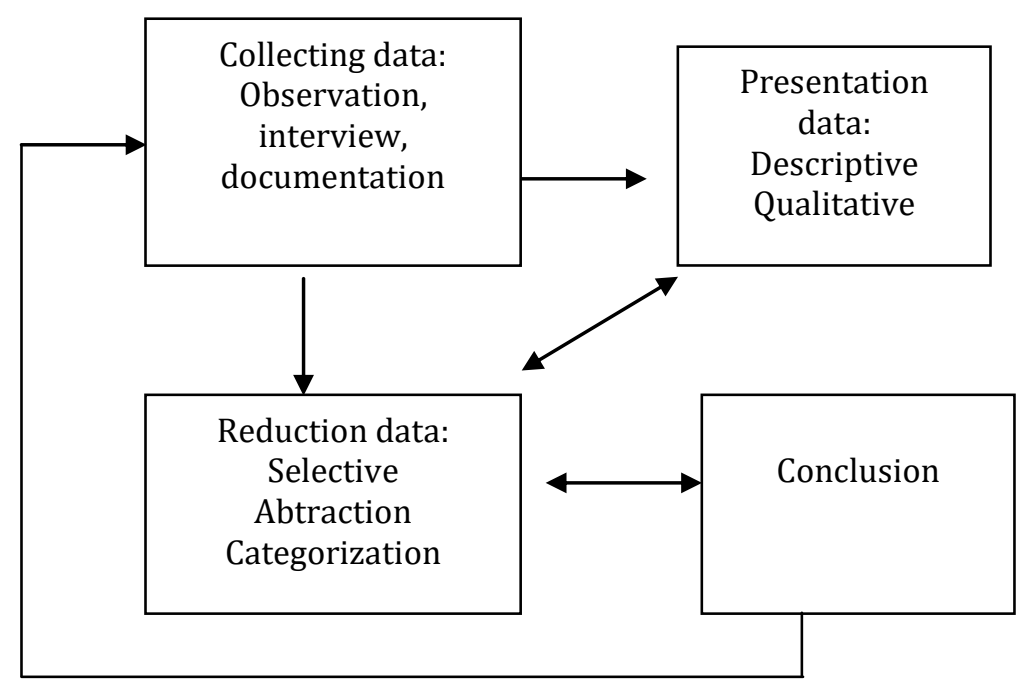

Source: Miles dan Huberman (1992)

Picture 1. Interactive Data Analysis

\section{Result and Discussion}

\section{A. Partnership Between Actors}

Empirical partnerships that occur are two patterns that can be observed from partnership partners. The first pattern is partnerships carried out at the business level, namely between cassava farmers (producers), brokers (renters), and tape entrepreneurs as small and medium enterprises (UKM). In this pattern, farmers produce cassava according to what the broker wants. Cassava is the main raw material for tape and brokers as suppliers of cassava needed by tape entrepreneurs. Cassava needed by tape entrepreneurs is yellow cassava, and consumers generally buy yellow cassava tape. To maintain continuity of supply, brokers usually provide capital loans to cassava farmers, as a form of bonding in the production, marketing, and prices of cassava.

The second pattern is the partnership carried out in the partnership triangle, namely the government, business world, and society. In the second pattern which includes the government, namely the central government, the provincial government, and the district government, as well as government institutions such as state universities. While those that belong to the business sector are cassava farmers as producers/entrepreneurs, tape entrepreneurs (UKM), tapioca flour factories as large companies, and Himpunan Petani Singkong Indonesia (HIPSINDO) as non-governmental institutions as part of civil society.

In the first pattern, brokers as rent-seekers have a dominant position both with farmers and with tape entrepreneurs. Brokers approach farmers in choosing seeds, technology, quality, and prices for postharvest cassava. In this pattern, farmers are more objects than other actors, brokers, and tape entrepreneurs. The implication is that farmers have no other alternative both in farming, using technology, and marketing. This pattern of the partnership between farmers and brokers and tape entrepreneurs is in an unequal relationship, not mutually beneficial, and does not raise each other. While the position of government officials, tend to be passive by submitting to the market mechanism. In this pattern, there is no effort to increase the business competitiveness of casłava farmers from business partners.

In the second pattern partnership, cassava farmers are positioned as subjects and business people who have the freedom to choose cropping patterns (intercropping corn-cassava), and their market share. The ability of farmers as such cannot be separated from the role of HIPSINDO as a mediator, negotiator, facilitator, and innovator. To improve the competitiveness of the farmers' sinking, HIPSINDO mediated and negotiated with tape (SME) entrepreneurs, tape sellers, and tapioca flour factories. In connection with tape sales shops, farmers were given skills in processing cassava into a tape. As a nongovernment institution, HIPSINDO communicated with the East Java Provincial Government regarding capital. As for the use of cropping patterns, technology, and marketing network development, HIPSINDO gained knowledge and expertise from participating in seminars, workshops, and training held by Brawidjaja University Malang. In this pattern, the local government provides capital facilities to improve 
the competitiveness of small-scale farmers' businesses through HIPSINDO. In this model, the relationships carried out by the actors are equal or balanced with mutual need, mutual benefit, and mutual rearing.

\section{B. Partnerships by Pattern and Competitiveness}

Partnerships carried out by the actors can be seen from the requirements, principles, and benefits that can show patterns, models, and their relation to the competitiveness of cassava. For example, the first pattern is tending towards pseudo partnerships with subordinate models. While the second partnership pattern is tending towards pseudo partnerships with collaborative models. Auxiliary models and collaborative models have implications for the competitiveness of cassava products. The term competitiveness is the same as competitive. Competitiveness is related to productivity and marketing.

Low competitiveness empirically shows, low productivity, access to market information, market share, and marketing network of cassava products produced by farmers is limited and narrow. The small thing in question is the buyer (who needs) cassava is only a tape businessman. On the contrary, competitiveness is said to be high if empirically shows, high productivity, open access to agricultural information, significant market share (diverse) and marketing network of cassava products produced by farmers is extensive.

The collaborative model of cassava farmers is positioned as the party that conducts cassava production business, and post-harvest processing is by the planting pattern that it does. To cassava farmers, HIPSINDO provides credit facilities, technology assistance and cropping patterns (intercropping), assistance with crop processing skills (tape and cake), provides marketing information, and mediation, negotiation, communication, and recommendations with tape manufacturers and sellers outside the region. Cassava was sent to the tapioca factory, which was recommended by HIPSINDO. Tape or cake products from cassava farmers, HIPSINDO helped offer, promote, determine market share and marketing networks outside the Bondowoso area.

The ability of the HIPSINDO management in carrying out functions and roles related to advocacy, negotiation, facilitation, capital, technology, and monitoring is inseparable from the support and assistance from universities. The support provided by the university involved HIPSINDO management in various seminars, workshops, focus group discussions, and training. Higher education has a contribution to increasing the competitiveness of cassava businesses, both through partnerships and institutional development. In this model, cassava, farmers receive capital loans, technology assistance, processing, and marketing information. Besides, that, farmers have freedom in cropping patterns (intercropping corn and cassava) and post-harvest processing and marketing.

In this model, farmers can process their crops by making their tapes sold through tape traders and can sell cassava to tape entrepreneurs (SMEs) directly, and prices are determined by agreement between cassava farmers and tape entrepreneurs. For cassava that can not be made, the tape is sold to tapioca flour pellets with recommendations from HISPINDO, including prices. The perception built on this model is cassava is a superior product. In this model, cassava can be processed at these farmers themselves into tape and cake, or sold to tape entrepreneurs and sold to flour factories. Even though this model is classified as a pseudo partnership, it is a highly competitive cassava farmer's business. In this case, farmers as cassava producers, they have also become entrepreneurs of tape and cakes from cassava. This model of farmers has information certainty related to value-added, competitiveness, and income and profits.

\section{Characteristics of the Partnership Model}

\section{1) Partnership Characteristics of the Subordinate Model}

In this pattern, farmers are not free to choose a cropping pattern, and cannot sell cassava directly to tape entrepreneurs, and or to flour mills. In this pattern, farmers are in a weak position, related to information on market prices, market share, and marketing networks of cassava. In this developing model, perspectives are that "cassava is the same as a tape." The implication is that the business competitiveness of cassava farmers is low and limited. Because cassava produced by farmers is only for tape. Consequently, if the cassava produced is not by the standards set by the broker and tape businessman, then the added value and competitiveness of the cassava produced will be low, because farmers have no other choice, related to seeds, cropping patterns and their supply. follows:

In this model, the partnerships between cassava farmers, brokers, and tape growers are as

1) In terms of requirements, there is one requirement that is not fulfilled from the four requirements, namely having the same vision in achieving the goal. In this context, farmers function more as objects that must fulfill and carry out the interests of tape brokers and entrepreneurs 
2) In terms of the principle of a partnership carried out not based on mutual benefit principles and shared development

3) In terms of the partnership model undertaken is a pseudo partnership with the Subordinate union of partnership model is a partnership between two or more parties whose strength or ability they have is not the same, or in an unequal or unbalanced position

4) In terms of benefits, the position of farmers as producers is weak, especially in decisions regarding the price, market share, and marketing of cassava produced. The implication is that farmers do not get optimal benefits. In terms of benefits, farmers have no other choice in cropping patterns, technology management, and marketing, because they have been determined by brokers

This pseudo partnership does not increase each other and is not mutually beneficial. Thus the characteristics of the subordinate model are as follows.

a) Local government apparatuses related to cassava farmers' efforts to increase their production competitiveness tend to be passive and more surrender to the market. Such an attitude of the apparatus, because cassava is not yet a priority and superior commodity in Bondowoso Regency. At the time of research of superior commodities, namely coffee, soybeans, and corn. The apparatus' perception of cassava is a tape (Cassava $=$ Tape)

b) Tape entrepreneurs (UKM) in maintaining or developing their business/industry, generally using brokerage services in maintaining the continuity of the supply of raw materials (cassava) they need from farmers (producers)

c) Brokers as rent-seekers are so dominant in maintaining the continuity of supply of cassava raw materials needed by tape entrepreneurs from farmers (producers). Brokers serve as business capital lenders (money from tape entrepreneurs) and play a role in determining the quality of products needed by tape entrepreneurs and controlling prices according to the interests of tape brokers and entrepreneurs

d) Farmers as producers in the production process are bound by an agreement (oral) with a broker. The agreement made is related to the type and quality of cassava grown. Usually, farmers are tied up with business capital loans (bonded patterns) by brokers

e) In this pattern, tape entrepreneurs (UKM) and brokers are in a stronger position, while farmers are in a weak position, in determining cropping patterns and marketing

\section{2) Characteristics of Collaborative Model Partnerships}

In this model, the cassava farmers institutionally as well as producers, there are also some farmers as tape/cake entrepreneurs from cassava. HIPSINDO as an association of civil society, provides credit facilities, technology assistance and cropping patterns (intercropping), assistance with harvest processing skills (tape and cake), provides marketing information, and mediation, negotiation, communication, and recommendations with tape manufacturers and sellers outside the area. To maintain the quality and continuity of supply, cassava sent by cassava farmers to the tapioca factory was recommended by HIPSINDO.

In the collaborative model, partnership partnerships between cassava farmers and HISPINDO, tape entrepreneurs, tape sellers, and tapioca flour factories are carried out according to partnership requirements. The agreement is made by the oral (unwritten) method. The partnership principles that need to get the attention of the partners, namely: mutual need, mutual trust, mutual reinforcement, and mutual benefit. Mutual benefits between the partners as a manifestation of mutual need and mutual reinforcement or mutual development. Through the functions of advocacy, facilitation, mediation, and innovation by HIPSINDO on cassava farmers, pseudo partnerships with collaborative models carried out with tape entrepreneurs, sellers and flour mills were carried out based on mutual need, mutual reinforcement, mutual trust, and mutual benefit.

The innovation taught by HIPSINDO to cassava farmers is related to the selection of cropping patterns (intercropping: maize with cassava), seeds and technology applications oriented to the needs of tape entrepreneurs and flour mills (market orientation). Innovation-supported partnerships encourage partner parties to need each other, mutual trust and mutual benefit in turn to foster each other. The collaborative model motivates partners based on mutual benefit and mutual nurturing. Examples of mutual benefits, namely for small, medium, and large enterprises (UKMB), namely the savings in production costs, guaranteed raw materials, saving investment capital. For farmers as small businesses, the existence of partnerships will encourage increased capacity and entrepreneurship, increase the income of families and rural communities, improve the quality of mastery of technology, the ability to utilize credit, control management and provision of employment, and in turn partnerships as a small community empowerment strategy. 
Collaboration on pseudo-pattern partnerships with collaborative models brings many benefits to the partners, especially cassava farmers. The benefits obtained by cassava farmers on collaborative models are productivity, efficiency, and quality assurance Increased productivity and efficiency of cassava farming, as well as the quality of cassava products produced as an embodiment of increasing competitiveness. The characteristics of the collaborative model partnership are as follows.

a) Local government apparatus, especially from the East Java provincial government which actively facilitates HIPSINDO through advocacy, facilitation (credit and technology) and the development of the business of cassava farmers

b) Cassava farmers are positioned as subjects (actors) who have the freedom to choose cropping, technology, and market-oriented patterns

c) Cooperation partnerships are carried out in partnership triangles based on the requirements, principles, and benefits of the partnership

d) Cooperation partnerships between farmers as producers with HIPSIND0, tape entrepreneurs, tape sellers, flour mills, and with the government and universities carried out in an artificial partnership pattern, but with a collaborative model

e) Collaborative model partnerships encourage the business of cassava farmers to be able to produce products with high added value and competitiveness in the local and inter-regional markets

f) Competitiveness of cassava is reflected in its market share and marketing network. More and more market share requires both cassavas as raw material and processed products, reflecting the high competitiveness of cassava

\section{Differences in Subordinative Model and Collaborative Model Partnerships}

The first model partnership views cassava farmers as objects, making them as agents who must carry out what is in the interests of brokers and tape entrepreneurs, especially those related to the required cassava. In the second model partnership, looking at cassava farmers as subjects and actors (producers and entrepreneurs) who have freedom in the production process. Therefore cassava farmers are not seen as agents but as their primary partners. In the first model partnership, it departs from the perception that "cassava is the same as a tape." The implication in this model is not creativity and innovation in the production process and post-harvest (industrial business). In the second model partnership, partnerships are built on the perception that cassava is the same as superior products. The implication is that farmers in facilities are producers who can increase productivity and efficiency, and are encouraged to become creative and innovative entrepreneurs.

The first model partnership, farmers do not have the freedom or other alternatives in the production process related to the type/variety (only cassava is suitable for tape) cropping patterns (only cassava plants), product quality (generally yellow cassava) determined in size. In this model, farmers do not have enough information to calculate the profits of their cassava businesses. While the second model partnership, farmers are given the freedom to choose cropping patterns, namely intercropping patterns (corn with cassava). In this model, farmers have enough information in calculating the profits of their farming businesses. For example, corn yields can be used to cover production costs, so benefits are collected from cassava harvests.

In the first model, farmers do not have enough information related to markets, market share, and marketing networks. Market share and competition are limited to collectors and brokers as middlemen. While the second model, farmers have market access, market share, and extensive marketing networks. The large market share and marketing network is one measure of the high competitiveness of cassava as a superior product. The first model, access to capital, technology, business management, and marketing, is limited. Wealth comes from brokers.

\section{E. Partnership Increases Competitiveness of Cassava Products}

The characteristics of partnerships that increase the competitiveness of cassava are as follows.

a) Cassava which is produced as a quality business product of farmers according to market needs,

b) Cassava produced by farmers is perceived by stakeholders as a superior commodity

c) Farmers are positioned as subjects and given freedom in choosing cropping patterns, technology, product quality, and in increasing the productivity of their farming businesses

d) Local government policy is to provide fair and fair access to cassava farmers in obtaining inputs, production processes, distribution without any obstacles in entering the market.

e) Motivated and facilitated to be creative and innovative business actors in managing and increasing the added value of the products produced

f) Farmers are assisted in having access to market information, market share and local, regional (interregional) and even national marketing networks 
g) Partnerships carried out in the partnership triangle scheme between the provincial government, the business world, and civil society

h) Organizations implemented are by the terms, principles, and benefits of the organization

\section{Conclusion}

The partnership that ran at the time of the research developed two partnership models in the research area, namely the collaboration of subordinate models and collaborative models. In the auxiliary model, the position of the farmer becomes the object, and the evolving perception that "cassava is the same as a tape." Such perceptions of stakeholders encourage the competitiveness of cassava to be narrow and limited. While in the collaborative model, farmers are positioned as subjects and business actors, with the perception of stakeholders that "cassava is the same as superior products." Such perceptions encourage the competitiveness of cassava to be high and wide.

Through partnerships between large and medium enterprises with small and weak farming, and facilitated by the government, and civil society, it can increase productivity, different market share, extensive marketing networks, and increase profits. This means that partnerships are built by the requirements, and are carried out by the principles of partnership, so the partners who are partners can encourage increased competitiveness of the products produced, and obtain optimal benefits.

The collaborative partnership model is an effective model to improve the competitiveness of cassava farmers' businesses related to productivity, product quality assurance, market share, and network marketing. This model encourages farmers as producers and empowering small businesses. Collaborative model partnerships involving the government, business, and civil society in the partnership triangle can increase the income and welfare of cassava farmers.

\section{Reference}

Azhari, Abdul Kholiq dan Abul Haris Suryo Negoro, 2019, Desentralisasi Dan Otonomi Daerah Di Negara Kesatuan Republik Indonesia, Malang: Intrans Publishing

Bobo, Julius, 2003. Transformasi Ekonomi Rakyat. Jakarta : CIDESINDO

Hafsah, Muhammad Jafar, 2000. Kemitraan Usaha: Konsepsi dan Strategi. Jakarta: PT Pustaka Sinar Harapan

Kaloh, J.,2002. Mencari Bentuk Otonomi Daerah : Suatu Solusi Dalam Menjawab Kebutuhan Lokal dan Tantangan Global. Jakarta : PT Rineka Cipta

Miles, B. Mathew dan Michael Huberman. 1992. Analisis Data Kualitatif Buku Sumber Tentang Metodemetode Baru. Jakarta: UIP.

Mubyarto, 1997. Ekonomi Rakyat, Program IDT dan Demorasi Ekonomi Indonesia. Yogyakarta :: Aditya Media

Piter Abdullah dkk (Ed) 2002. Daya Saing Daerah : Konsep dan Pengukurannya di Indonesia. Yogyakarta : BPFE

Pratikno 2010. Peningkatan Kapasitas Berjejaring Dalam Tata Pemerintahan Yang Demokratis. Dalam Wahyudi Kumorotomo dan Ambar Widayaningrum (ed) Reformasi Aparatur Negara Ditinjau Kembali. Yogyakarta, Gava Media.

Sulistiyani, Ambar Teguh, 2004. Kemitraan dan Model-Model Pemberdayaan. Yogyakarta : Gava Media

Suprijadi, Anwar, 2004. Etika Birokrasi Dalam Mewujudkan Good Governance. Jurnal Good Governance STIA LAN Vol. 3 No. 1 Mei Halaman 1-8 
Tjokroamidjojo, Bintoro, 2004, Merumuskan dan Melaksanakan Kebijakan Publik Berdasarkan PrinsipPrinsip Kepemerintahan Yang Baik (Good Governance). Jurnal Good Governance STIA LAN Vol. 3 No. 1 Mei Halaman 43-46

Wahab, Solichin Abdul, 1999, Ekonomi Politik Pembangunan : Bisnis Indonesia Era Orde Baru dan Ditengah Krisis Moneter. Malang : PT Danar Wijaya-Brawijaya University Press 